\title{
Vocal Cord Biopsy
}

National Cancer Institute

\section{Source}

National Cancer Institute. Vocal Cord Biopsy. NCI Thesaurus. Code C51908.

Removal of tissue from the vocal cords for microscopic examination. 